\title{
EFFECT OF THE ELEVATED-TEMPERATURE-PRECIPITATION IN
}

\section{ALLOY 625 ON PROPERTIES AND MICROSTRUCTURE}

\author{
M. Köhler \\ VDM Nickel-Technologie $A G$ \\ D-5980 WerdohI, Ge many
}

\begin{abstract}
Alloy 625 exhibits a complex precipitation behavior at elevated temperatures due to the high alloying constituents of molybdenum and niobium. Furthermore, the precipitation behavior will depend upon the carbon content and the final annealing temperature. Stability studies have been conducted on plate material of alloy 625 . The time-temperature-strength and ductility behavior has been examined in the temperature range of $600-1000^{\circ} \mathrm{C}$ as a function of the final annealing temperature and the carbon content. A severe loss of notch impact strength at room temperature after exposure in the temperature range of $600-800^{\circ} \mathrm{C}$ has been determined. This loss of ductility can be correlated above all to gamma double prime and carbide precipitation. The loss of ductility can be mitigated considerably by controlling the carbon content together with the final annealing treatment.
\end{abstract}

\section{Introduction}

Alloy 625 is a high temperature resistant nickel base alloy which shows an excellent resistance also to many wet corrosive environments. According to its use it is supplied either in the soft-annealed condition or in the solution annealed condition. Due to its high contents of molybdenum, chromium and niobium, alloy 625 stands out for its complex precipitation behavior. In addition, this alloy is usually melted with relatively high carbon contents. As a result, dependent on the heat treatment carbides of type $M_{6} C$ and $M_{23} C_{6}$ can be found besides carbonitrides. It is, therefore, to be expected that the characteristics of alloy 625 will be influenced by this precipitates during exposure to high temperatures.

\footnotetext{
Superalloys 718, 625 and Various Derivatives Edited by Edward A. Loria

The Minerals, Metals \& Materials Society, 1991
} 
It was already mentioned by $F$. A. Comprelli and co-workers (1-3) that alloy 625 can be aged at elevated temperatures. They found a remarkable increase in hardness, yield strength and tensile strength as well as a significant decrease of elongation after aging at $700^{\circ} \mathrm{C}$.

F. A. Comprelli and co-workers assumed that this was due to the precipitation of a coherent $\mathrm{Ni}_{3}(\mathrm{Nb}, \mathrm{Al}, \mathrm{Ti})$-phase. Research work of $\mathrm{H}$. Böhm and co-workers (4) has then shown that the increase in hardness at temperatures $\geq 750^{\circ} \mathrm{C}$ is caused by the precipitation of a stable incoherent orthorhombic $\mathrm{Ni}_{3}(\mathrm{Nb}, \mathrm{Mo})$-phase. At $675^{\circ} \mathrm{C}$ they observed the metastable (coherent tetragonal $\mathrm{Ni}_{3}(\mathrm{Nb}, X)$ phase which, however, can be transformed into the orthorhombic phase $\mathrm{Ni}_{3}(\mathrm{Nb}, \mathrm{Mo})$ after long time exposure. The precipitation behavior of alloy 625 has been summarized for the first time by $E$. Schnabel and co-workers (5) in a comprehensive time-temperature-transformation diagram (Fig.I). For the solution annealed alloy $625 \mathrm{~J}$. R. Crum and co-workers (6) have recently published a revised time-temperature-transformation diagram (Fig.2). Both diagrams differ mainly in the sequence of precipitation of the carbides of type $M_{23} C_{6}$ and $M_{6} C$. Due to the very complex precipitation behavior a ductility minimum can be expected in the temperature range from $600^{\circ} \mathrm{C}$ to $800^{\circ} \mathrm{C}$.

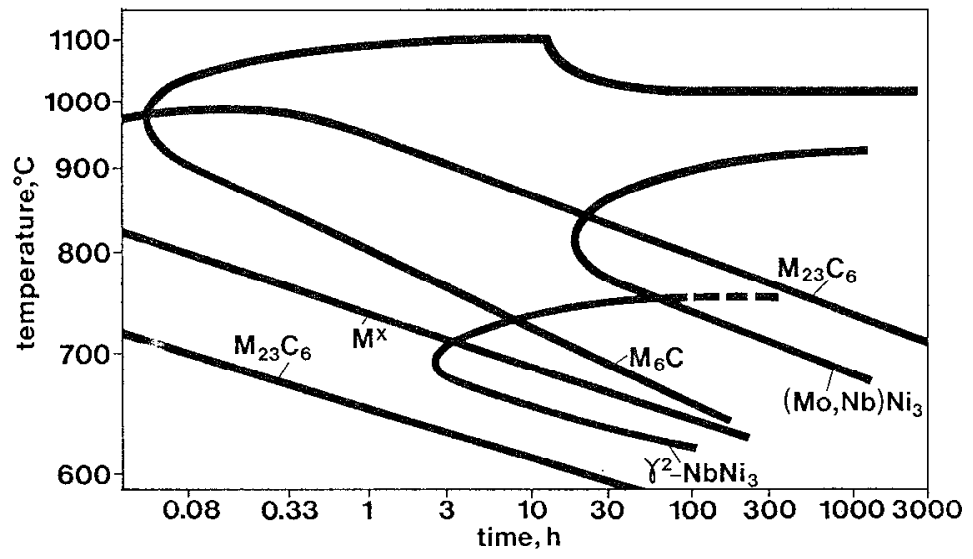

Fig. 1: Time-temperature-transformation diagram

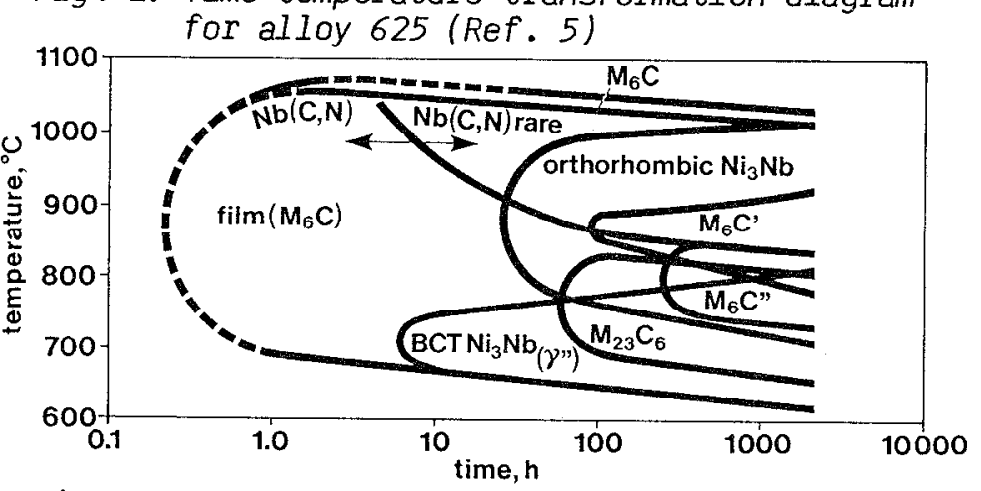

Fig. 2: Time-temperature-transformation diagram for solution treated alloy 625 (Ref. 6) 
The influence of high temperature exposure of alloy 625 on the mechanical properties and particularly on the ductility behavior has been published by 0. F. Kimball and co-workers (7). They have shown that the Charpy impact strength after exposure at a temperature between 540 and $760^{\circ} \mathrm{C}$ will decrease significantly and that the fracture characteristics change from ductile and transgranular to brittle and intergranular.

According to O. F. Kimball and co-workers the loss of ductility is caused by the precipitation hardening and the formation of continuous brittle grain boundary precipitates.

This study concentrates on the influence of the niobium and carbon contents as well as on the influence of the final annealing treatment on the precipitation behavior and the loss of ductility of alloy 625 during annealing at temperatures ranging from $600-1000^{\circ} \mathrm{C}$. The effect of thermal aging on room temperature tensile properties and room temperature impact strength as well as on elevated temperature tensile properties has been evaluated.

\section{Experimental}

As starting material two hot rolled plates of $12 \mathrm{~mm}$ thickness of alloy 625 were used, which, according to Table 1, differed significantly in their niobium and carbon contents. In advance of thermal aging, parts of these plates have been annealed at $980^{\circ} \mathrm{C}, 1050^{\circ} \mathrm{C}$ and $1120^{\circ} \mathrm{C}$ for 50 minutes each. The thermal aging matrix covers in $100^{\circ} \mathrm{C}$ steps the temperature range from $600-1000^{\circ} \mathrm{C}$ and the times of 10,100 and 1000 hours. All samples have been tested transverse to the rolling direction. Besides testing the mechanical properties at room temperature, tensile tests at aging temperature have been carried out after aging.

\begin{tabular}{|l|c|c|c|c|c|c|c|c|c|c|}
\hline & $\mathrm{Cr}$ & $\mathrm{Ni}$ & $\mathrm{Mo}$ & $\mathrm{Fe}$ & $\mathrm{Mn}$ & $\mathrm{Si}$ & $\mathrm{Ti}$ & $\mathrm{Nb}+\mathrm{Ta}$ & $\mathrm{Al}$ & $\mathrm{C}$ \\
\hline alloy 625 & $\begin{array}{l}20.0- \\
23.0\end{array}$ & $<58$ & $\begin{array}{c}8.0- \\
10.0\end{array}$ & $<5.0$ & $<0.5$ & $<0.5$ & $<0.4$ & $\begin{array}{l}3.15- \\
4.15\end{array}$ & $<0.4$ & $<0.1$ \\
\hline $\begin{array}{l}\text { Nicrofer 6020 hMo } \\
\text { heat:76502 }\end{array}$ & 22.25 & bal. & 9.27 & 2.05 & 0.1 & 0.04 & 0.3 & 3.42 & 0.14 & 0.011 \\
\hline $\begin{array}{l}\text { Nicrofer 6022 hMo } \\
\text { heat:82310 }\end{array}$ & 21.9 & bal. & 8.94 & 1.4 & 0.03 & 0.04 & 0.18 & 3.74 & 0.16 & 0.03 \\
\hline
\end{tabular}

Table 1: Chemical composition of the experimental material in comparison to the ASTM requirements for alloy 625 


\section{Results and Discussion}

\section{Room temperature properties as a function of final annealing treatment}

Fig. 3 and 4 show the microstructure of the starting material. After final annealing at temperatures of $980^{\circ} \mathrm{C}$ and $1050^{\circ} \mathrm{C}$ carbides could not be solved completely and, therefore, a grain growth cannot occur. At $1120^{\circ} \mathrm{C}$ both alloy variations show grain growth, which can be correlated to the carbon content of the alloys. In addition, Table 2 summarizes the results of impact testing for both alloy variations as a function of the final annealing temperature. As was to be expected, the alloy with the lower carbon content stands out for higher impact values at any temperature.

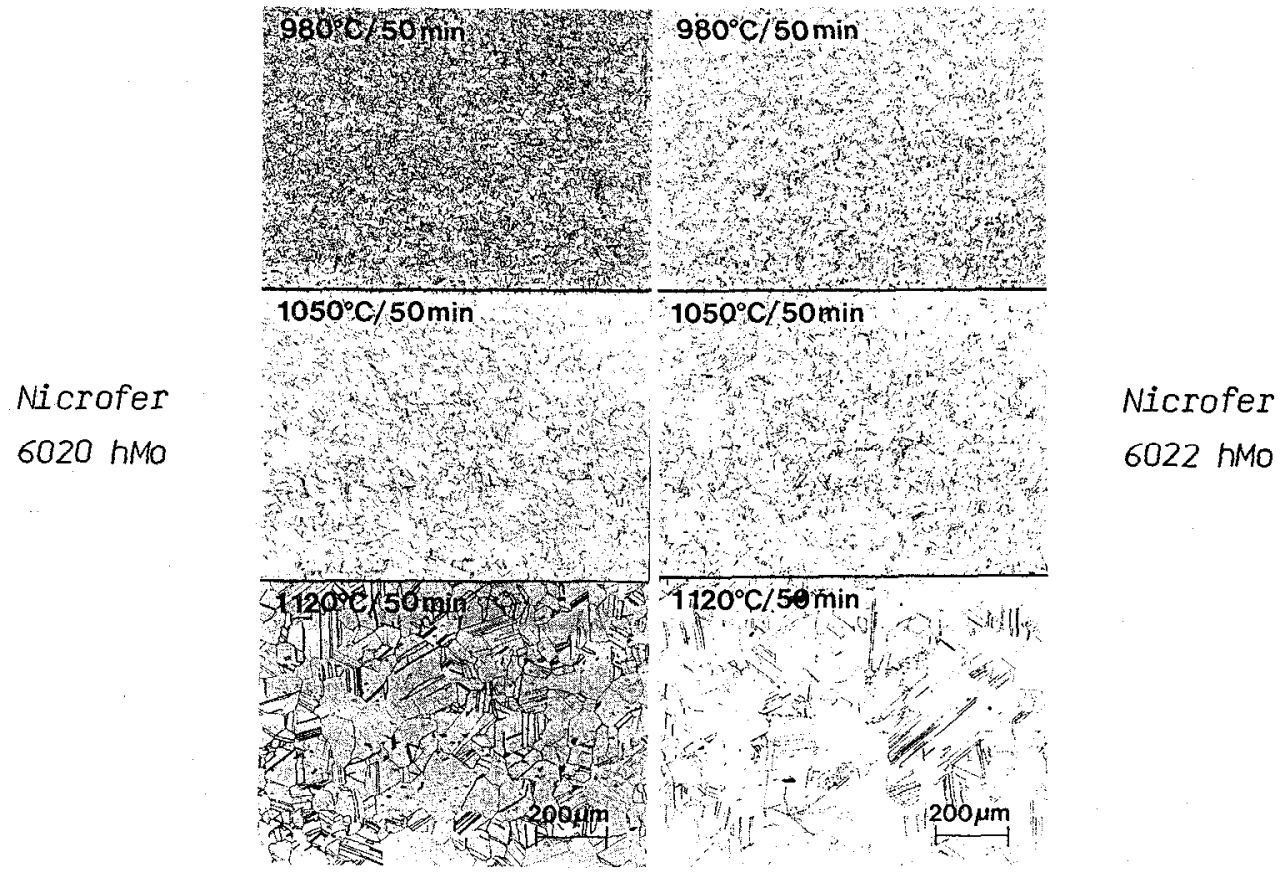

Fig. 4 and 5: Microstructure as a function of the final annealing temperature

\begin{tabular}{|l|c|c|c|}
\hline & $980^{\circ} \mathrm{C}$ & $1050^{\circ} \mathrm{C}$ & $1120^{\circ} \mathrm{C}$ \\
\hline $\begin{array}{l}\text { Nicrofer } 6020 \mathrm{hMo} \\
\text { heat } 76502\end{array}$ & $152 \mathrm{~J} / \mathrm{cm}^{2}$ & $186 \mathrm{~J} / \mathrm{cm}^{2}$ & $211 \mathrm{~J} / \mathrm{cm}^{2}$ \\
\hline $\begin{array}{l}\text { Nicrofer } 6022 \mathrm{hMo} \\
\text { heat } 82310\end{array}$ & $135 \mathrm{~J} / \mathrm{cm}^{2}$ & $178 \mathrm{~J} / \mathrm{cm}^{2}$ & $188 \mathrm{~J} / \mathrm{cm}^{2}$ \\
\hline
\end{tabular}

Table 2: Effect of final annealing on Charpy-notch-impact energy of alloy 625 variations. Results of tests at room temperature on ISO-V-notch samples 
Room temperature properties as a function of thermal aging

In a second step, the Charpy-notch impact valucs for both alloy variations with their 3 final annealing variations each have been evaluated as a function of aging time and temperature. In order to compare the tested sample variations ISO impact energy curves have been determined from the experimental results for the impact energy values of $50 \mathrm{~J} / \mathrm{cm}^{2}, 100 \mathrm{~J} / \mathrm{cm}^{2}$ and $150 \mathrm{~J} / \mathrm{cm}^{2}$. Figure 5 and 6 show, as an example, the results for the two test variations, i.e. Nicrofer $6020 \mathrm{hMo}$ finally annealed at $1120^{\circ} \mathrm{C}$ and Nicrofer $6022 \mathrm{hMo}$ finally annealed at $980^{\circ} \mathrm{C}$. The absolutely lowest impact energy values have been found after thermal aging over 1000 hours at 700 and $800^{\circ} \mathrm{C}$ in all test variations. This severe ductility loss was caused by the precipitation of the tetragonal $\mathrm{Ni} 3_{3} \mathrm{Nb}$-phase and the orthorhombic $\mathrm{Ni}_{3}(\mathrm{Nb}, \mathrm{MO})$-phase. However, even after thermal aging at $600^{\circ} \mathrm{C}$ a decrease in impact energy values of $50 \%$ with regard to the starting condition can be observed after 1000 hours.

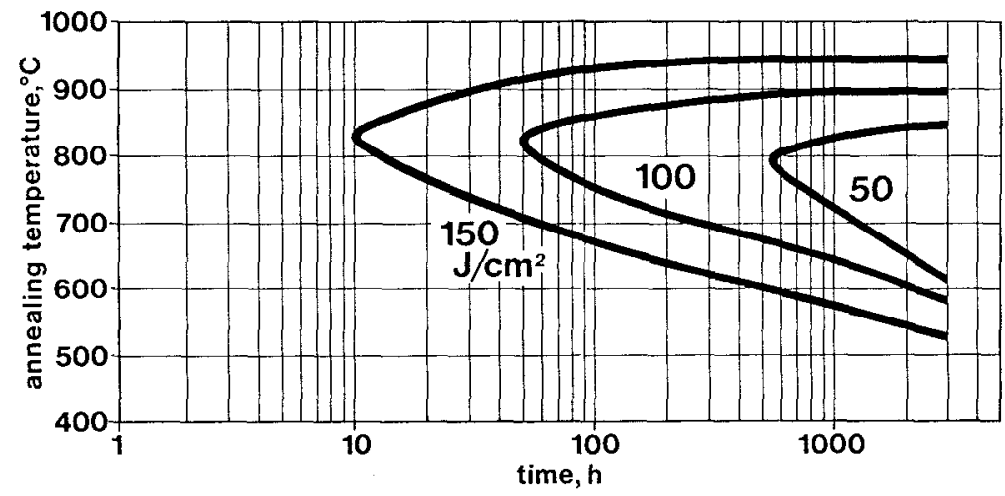

Fig. 5: ISO-notch impact curves for Nicrofer $6020 \mathrm{hMO}$ annealed at $1120^{\circ} \mathrm{C} / 50 \mathrm{~min}$ and aged as shown.

Results of tests at room temperature on ISO-V-notch samples

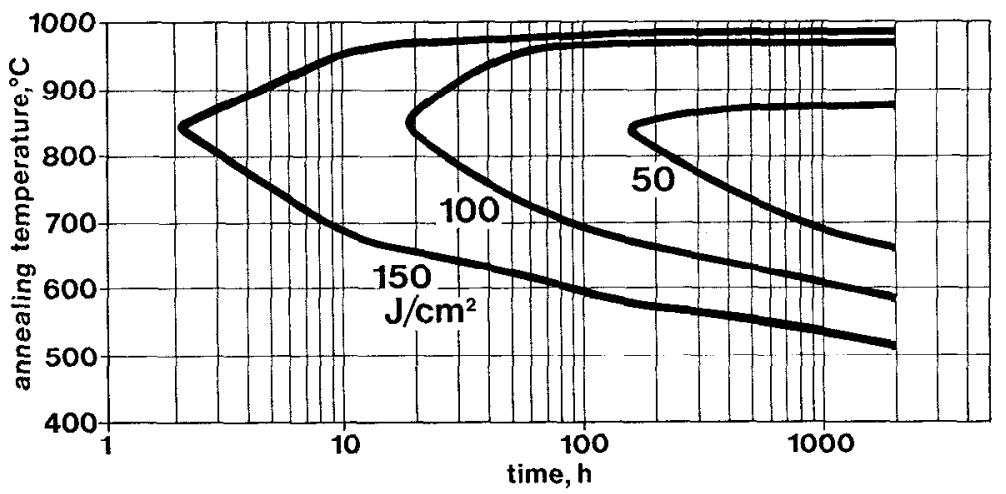

Fig. 6: ISO-notch impact curves for Nicrofer 6022 hMo annealed at $980^{\circ} \mathrm{C} / 50 \mathrm{~min}$ and aged as shown.

Results of lests at room temperature on ISO-V-notch samples 
At higher temperatures only thermal aging at $1000^{\circ} \mathrm{C}$ did not end in a ductility loss. A comparison of the iso-impact-energy curves indicated that the "noses" of the iso-impact-energy curves have shifted with higher niobium and carbon contents to higher temperatures. If the results are evaluated with regard to the minimal thermal aging time needed to reach $50 \mathrm{~J} / \mathrm{cm}^{2}$ (Fig. 7), it can be seen that solution annealing at $1120^{\circ} \mathrm{C}$ should be preferred to soft annealing at $980^{\circ} \mathrm{C}$. An extremely negative result was observed at a final annealing temperature of $1050^{\circ} \mathrm{C}$. If, in addition, both alloy variations are compared, alloy Nicrofer $6020 \mathrm{hMo}$, which has the lower carbon and niobium contents, stands out for its smaller ductility loss. A decrease to an impact-energy value of $50 \mathrm{~J} / \mathrm{cm}^{2}$ is to be expected after 550 hours at the earliest whereas the alloy variation with the higher carbon and niobium contents drops to this value after about 260 hours already.

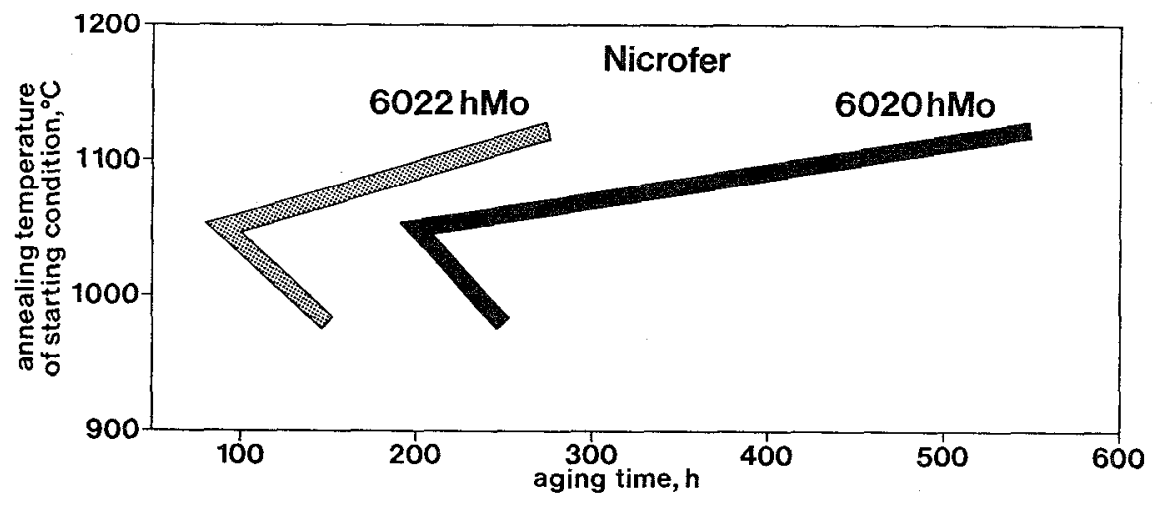

Fig. 7: Aging time to meet a Charpy-notch-impact energy value of $50 \mathrm{~J} / \mathrm{cm}^{2}$ depending on final annealing temperature and alloy composition according to tests at room temperature on ISO-V-notch samples.

The influence of thermal aging on hardness is shown in Fig. 8 and 9 . The highest hardness values have been found at $700^{\circ} \mathrm{C}$. Nevertheless, after 100 hours an overaging effect could be observed. Thermal aging at $600^{\circ} \mathrm{C}$ will not result in an overaging effect in the test period of 1000 hours. The same applies for thermal aging at $800^{\circ} \mathrm{C}$, up to 1000 hours a continuous increase of hardness could be observed. Aging at $900^{\circ} \mathrm{C}$ shows no change in the hardness values. Only aging at $1000^{\circ} \mathrm{C}$ leads to a slight decrease in hardness compared to the starting condition. 
Effect of aging time and temperature on Brinell hardness

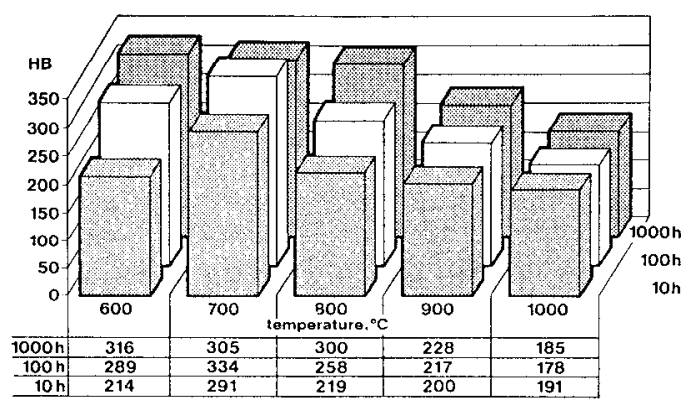

Fig.: 8 Nicrofer 6020 hMo starting condition: annealed at $980^{\circ} \mathrm{C}, H B=213$

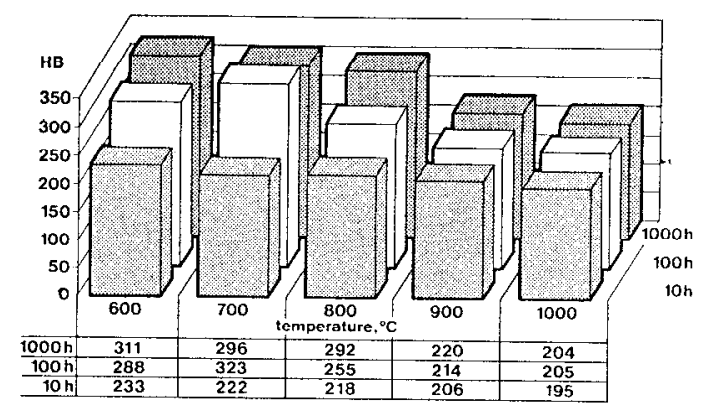

Fig. 9: Nicrofer 6022 hMo starting condition: annealed at $1120^{\circ} \mathrm{C}, \mathrm{HB}=232$

Similar results with regard to the increase of the hardness values as a function of aging time and temperature have been published by $\mathrm{H}$. Böhm (4). He reported a continuous increase in hardness after aging at $675^{\circ} \mathrm{C}$ over 1000 hours and correlated this increase with the precipitation of the tetragonal phase $\mathrm{Ni}_{3}(\mathrm{Nb}, X)$. At an aging temperature of $750^{\circ} \mathrm{C} \mathrm{H}$. Böhm found an overaging effect which was caused by the primary precipitation of the metastable tetragonal phase $\mathrm{Ni}_{3}(\mathrm{Nb}, X)$ and the secondary precipitation of the orthorhombic phase $\mathrm{Ni}_{3}(\mathrm{Nb}, \mathrm{MO})$.

Figures 10 and 11 show the influence of high temperature aging on the $0.2 \%$ yield strength tested at room temperature and for the final annealing condition of $980^{\circ} \mathrm{C}$ for both alloy variations. Above all it has to be mentioned that the increase in yield strength is very sluggish. The fastest aging response was observed at $700^{\circ} \mathrm{C}$. This applies for both alloy variations and all starting annealing conditions.

Effect of aging time and temperature on yield strength

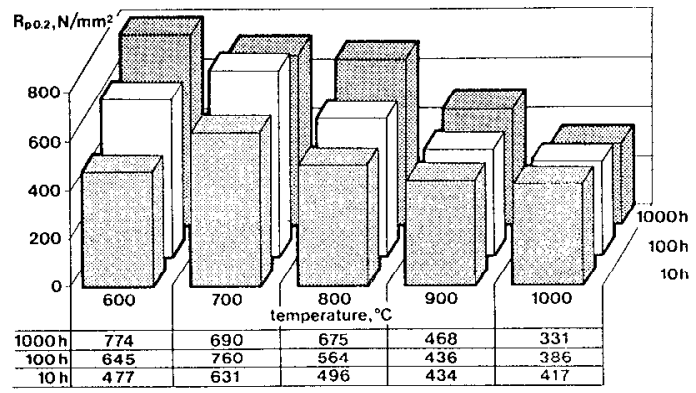

Fig. 10 Nicrofer $6020 \mathrm{hmo}$ starting condition: annealed at $980^{\circ} \mathrm{C}$ $R_{p 0.2}=482 \mathrm{~N} / \mathrm{mm}^{2}$

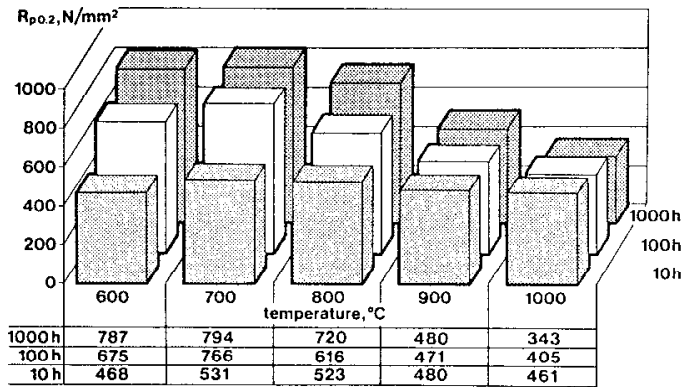

Fig. 11: Nicrofer 6022 hMo starting condition: annealed at $980^{\circ} \mathrm{C}$

$R_{p 0.2}=549 \mathrm{~N} / \mathrm{mm}^{2}$ 
As was expected, the difference in strength levels remains after high temperature aging. The highest strength levels, which can be reached by high temperature aging, are to be expected at $650^{\circ} \mathrm{C}$. At $900^{\circ} \mathrm{C}$ and above there will be no further increase in yield strength. The influence of the final annealing condition and the additional high temperature aging at $800^{\circ} \mathrm{C} / 1000$ hours on the elongation $\left(A_{5}\right)$ tested at room temperature, can be taken as an example for the alloy variations which are summarized in Table 3.

\begin{tabular}{|l|c|c|}
\hline annealing condition & $\begin{array}{l}\text { Nicrofer } 6020 \mathrm{hMo} \\
\text { heat } 76502\end{array}$ & $\begin{array}{l}\text { Nicrofer } 6022 \mathrm{hMo} \\
\text { heat } 82310\end{array}$ \\
\hline $980^{\circ} \mathrm{C} / 50 \mathrm{~min}$ & $50 \%$ & $46 \%$ \\
\hline$+800^{\circ} \mathrm{C} / 1000 \mathrm{~h}$ & $11 \%$ & $13 \%$ \\
\hline $1050^{\circ} \mathrm{C} / 50 \mathrm{~min}$ & $46 \%$ & $52 \%$ \\
\hline$+800^{\circ} \mathrm{C} / 1000 \mathrm{~h}$ & $11 \%$ & $17 \%$ \\
\hline $1120^{\circ} \mathrm{C} / 50 \mathrm{~min}$ & $39 \%$ & $60 \%$ \\
\hline$+800^{\circ} \mathrm{C} / 1000 \mathrm{~h}$ & $17 \%$ & $22 \%$ \\
\hline
\end{tabular}

Table 3: Effect of final annealing and additional aging on the elongation $\left(A_{5}\right)$ tested at room temperature of alloy 625 variations

It is obvious that higher final annealing temperatures result in a smaller decrease in elongation after aging. Due to its finer microstructure the alloy variation with a higher carbon content reaches the higher elongation values, irrespective of the individual annealing conditions. No decrease in elongation was observed after aging at $1000^{\circ} \mathrm{C}$. Aging at $600^{\circ} \mathrm{C}$ resulted in a decrease in elongation of $30 \%$ after 1000 hours correlated to the starting condition. This value is significantly lower than the decrease in impactenergy. If these ductility values are compared with the results of the impact testing, the first interim result is that the solution annealed alloy variation of Nicrofer 6020 hMo with the lower carbon content shows the smaller loss of ductility towards impact bending. However, in case of slow plastic deformation the alloy variation with the higher carbon content is to be preferred. 
High temperature strength as a

function of aging temperature

The influence of the final annealing conditions and the additional aging on the mechanical properties at room temperature and at aging temperature of $800^{\circ} \mathrm{C}, 700^{\circ} \mathrm{C}$ and $600^{\circ} \mathrm{C}$, are shown in Table 4. For comparison purposes the values determined directly after the final annealing of the plates are also given. It can be seen that the effect of strengthening combined with a severe ductility loss only occurs if the material is tested at room temperature. Testing at an aging temperature of $800^{\circ} \mathrm{C}$ shows virtually no strengthening and no serious ductility loss $\left(A_{5}\right)$. Aging the material at temperatures of 600 or $700^{\circ} \mathrm{C}$, however, leads to an increase in yield strength. This applies also if the material is tested at aging temperature. Nevertheless, the lowest strength levels have been determined after solution annealing at $1120^{\circ} \mathrm{C}$ and additional aging. Fur thermore, it could be seen that, with respect to a good plastic ductility behavior, a higher solution annealing temperature is to be preferred to soft annealing.

\begin{tabular}{|c|c|c|c|c|c|}
\hline \multirow[b]{2}{*}{ annealing condition } & \multirow[b]{2}{*}{$\begin{array}{l}\text { testing } \\
\text { temperature }\end{array}$} & \multicolumn{2}{|c|}{ Nicrofer $6020 \mathrm{hMo}$} & \multicolumn{2}{|c|}{ Nicrofer $6022 \mathrm{hMo}$} \\
\hline & & $\mathrm{Rp} 0.2 \mathrm{in} \mathrm{N} / \mathrm{mm}^{2}$ & $\Lambda_{s}$ in $\%$ & 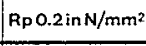 & $A_{3} \operatorname{in} \%$ \\
\hline $980^{\circ} \mathrm{C} / 50 \mathrm{~min}$ & RT & 482 & 50 & 549 & 46 \\
\hline \multirow{2}{*}{$+800^{\circ} \mathrm{C} / 1000 \mathrm{~h}$} & RT & 675 & 11 & 720 & 13 \\
\hline & $800^{\circ} \mathrm{C}$ & 442 & 40 & 520 & 22 \\
\hline $1050^{\circ} \mathrm{C} / 50 \mathrm{~min}$ & $\mathrm{RT}$ & 435 & 46 & 426 & 52 \\
\hline \multirow{2}{*}{$+800^{\circ} \mathrm{C} / 1000 \mathrm{~h}$} & RT & 695 & 11 & 775 & 17 \\
\hline & $800^{\circ} \mathrm{C}$ & 397 & 52 & 442 & 43 \\
\hline $1120^{\circ} \mathrm{C} /$ & RT & 382 & 37 & 414 & 60 \\
\hline \multirow{2}{*}{$+800^{\circ} \mathrm{C} / 1000 \mathrm{~h}$} & RT & 636 & 17 & 732 & 22 \\
\hline & $800^{\circ} \mathrm{C}$ & 397 & 35 & 440 & 50 \\
\hline
\end{tabular}

\begin{tabular}{|c|c|c|c|c|c|}
\hline \multirow[b]{2}{*}{ annealing condition } & \multirow{3}{*}{\begin{tabular}{|c|}
$\begin{array}{l}\text { testing } \\
\text { temperature }\end{array}$ \\
RT \\
\end{tabular}} & \multicolumn{2}{|c|}{ Nicrofer $6020 \mathrm{hMo}$} & \multicolumn{2}{|c|}{ Nicrofer $6022 \mathrm{hMo}$} \\
\hline & & $R p 0.2 \mathrm{inN} / \mathrm{mm}^{2}$ & $A_{5}$ in $\%$ & $\mathrm{Rp} 0.2 \mathrm{in} \mathrm{N} / \mathrm{mm}^{2}$ & $A_{5} \operatorname{in} \%$ \\
\hline $980^{\circ} \mathrm{C} /$ & & 482 & 50 & 549 & 46 \\
\hline \multirow{2}{*}{$+600^{\circ} \mathrm{C} / 1000 \mathrm{~h}$} & $\mathrm{RT}$ & 774 & 26 & 787 & 39 \\
\hline & $600^{\circ} \mathrm{C}$ & 611 & 23 & 594 & 28 \\
\hline $1050^{\circ} \mathrm{C} /$ & RT & 4.35 & 46 & 426 & 52. \\
\hline \multirow{2}{*}{$+600^{\circ} \mathrm{C} / 1000 \mathrm{~h}$} & RT & 814 & 29 & 905 & 33 \\
\hline & $600^{\circ} \mathrm{C}$ & 667 & 29 & 713 & 31 \\
\hline $1120^{\circ} \mathrm{C} /$ & RT & 382 & 39 & 414 & 60 \\
\hline \multirow{2}{*}{$+600^{\circ} \mathrm{C} / 1000 \mathrm{~h}$} & RT & 655 & 47 & 743 & 39 \\
\hline & $600^{\circ} \mathrm{C}$ & 533 & 36 & 572 & 32 \\
\hline
\end{tabular}

Table 4

\begin{tabular}{|c|c|c|c|c|c|}
\hline \multirow[b]{2}{*}{ annealing condition } & \multirow[b]{2}{*}{\begin{tabular}{|l|} 
testing \\
temperature
\end{tabular}} & \multicolumn{2}{|c|}{ Nicrofer $6020 \mathrm{hMo}$} & \multicolumn{2}{|c|}{ Nicrofer $6022 \mathrm{hMo}$} \\
\hline & & $R p 0.2$ in N//mm & $A_{5}$ in $\%$ & $R p 0.2 \mathrm{in} \mathrm{N} / \mathrm{mm}^{2}$ & $A_{5} \operatorname{in} \%$ \\
\hline $980^{\circ} \mathrm{C} / 50 \mathrm{~min}$ & RT & 482 & 50 & 549 & 46 \\
\hline \multirow{2}{*}{$+700^{\circ} \mathrm{C} / 1000 \mathrm{~h}$} & RT & 690 & 21 & 794 & 26 \\
\hline & $700^{\circ} \mathrm{C}$ & 589 & 32 & 557 & 15 \\
\hline $1050^{\circ} \mathrm{C} / 50 \mathrm{~min}$ & RT & 435 & 46 & 426 & 52 \\
\hline \multirow[b]{2}{*}{$+700^{\circ} \mathrm{C} / 1000 \mathrm{~h}$} & $\mathrm{RT}$ & 805 & 15 & 885 & 20 \\
\hline & $700^{\circ} \mathrm{C}$ & 581 & 19 & 623 & 19 \\
\hline $1120^{\circ} \mathrm{C} /$ & RT & 382 & 39 & 414 & 60 \\
\hline \multirow{2}{*}{$+700^{\circ} \mathrm{C} / 1000 \mathrm{~h}$} & RT & 686 & 21 & 686 & 28 \\
\hline & $700^{\circ} \mathrm{C}$ & 500 & 25 & 501 & 24 \\
\hline
\end{tabular}

Effect of final annealing and additional aging on the mechanical properties of alloy 625 variations tested at various conditions 
A comparison of both alloy variations shows the alloy composition Nicrofer 6020 hMo to have the better plastic behavior in the temperatures range of about $600-700^{\circ} \mathrm{C}$, being important for bellow and related applications, whereas in case of higher temperatures $\left(800^{\circ} \mathrm{C}\right)$ Nicrofer 6020 hMo is better.

The microstructure after high temperature aging

The influence of aging on the microstructure after holding at $800^{\circ} \mathrm{C}$ for 1000 hours is shown in Fig. 12. The comparison contains both alloy variations and the influence of the final annealing treatment of the plates. The needle-like precipitates have been identified as the orthorhombic $\mathrm{Ni}_{3}$ ( $\mathrm{Nb}, \mathrm{Mo}$ )phase, which caused the severe loss of ductility at this temperature. Moreover, on the grain boundaries $\mathrm{M}_{23} \mathrm{C}_{6}$ and $\mathrm{M}_{6} \mathrm{C}$ carbides could be identified. The smallest loss of ductility was shown with the microstructure according to Fig. $12 \mathrm{~A}$. The smaller ductility loss is due to the coarser grain structure and the lower content of $\mathrm{Ni}_{3}(\mathrm{Nb}, \mathrm{MO})$-phase.

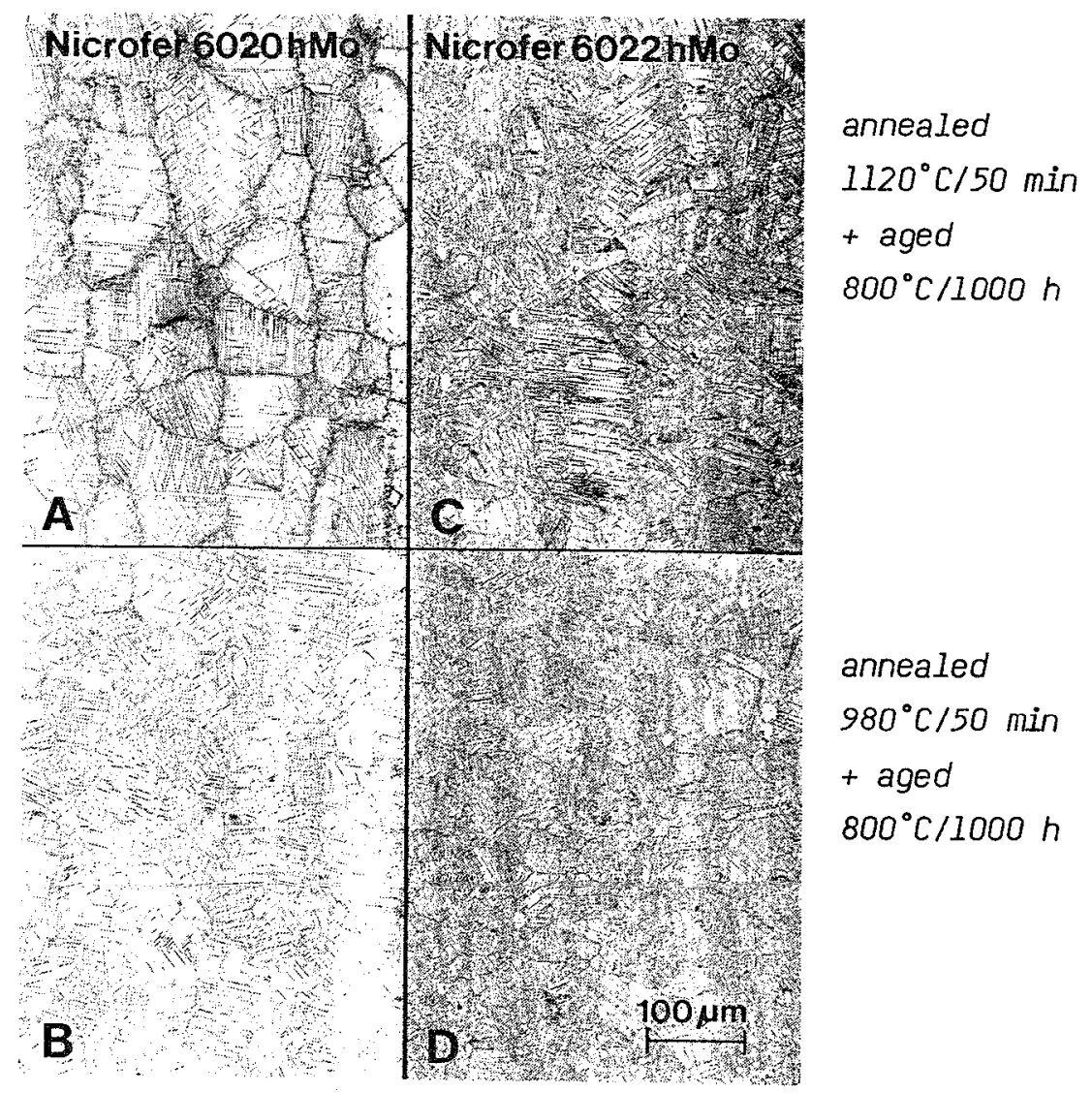

Fig. 12: Microstructure of alloy 625 variations after aging at $800^{\circ} \mathrm{C} / 1000 \mathrm{~h}$ as a function of the final annealing temperature 


\section{Conclusions}

The influence of the chemical analysis and the final annealing treatment on the precipitation and ductility behavior of alloy 625 has been studied. The most important conclusions are as follows:

- After high temperature aging at 600 - $900^{\circ} \mathrm{C}$ alloy 625 shows a severe ductility loss. The lowest impact energy values have been determined after aging at $700-800^{\circ} \mathrm{C}$. The ductility loss is caused by the precipitation of $\mathrm{Ni}_{3}(\mathrm{Nb}, \mathrm{Al}, \mathrm{Ti})$-phase and the orthorombic $\mathrm{Ni}_{3}(\mathrm{Nb}, \mathrm{Mo})$-phase. The latter has a most severe influence on the ductility.

- The ductility behavior of alloy 625 can be influenced by a variation of the carbon and niobium contents. A limitation of the carbon content to $\leqq 200 \mathrm{ppm}$ and of the niobium content to $\leqq 3,6 \%$ reduces the ductility loss significantly.

- Furthermore, the final annealing temperature can influence the ductility behavior of alloy 625 . An annealing temperature of $1120^{\circ} \mathrm{C}$ causes a noticeable shift in the decrease in impact energy values to longer times. An extremely negative effect, however, has a final annealing temperature of $1050^{\circ} \mathrm{C}$.

- The greatest increase in yield strength of alloy 625 can be expected after aging at $650^{\circ} \mathrm{C}$. up to aging times of 100 hours there will be no overaging. The ISO-V-notch impact energy at room temperature of a material which has been aged under these conditions is above $80 \mathrm{~J} / \mathrm{cm}^{2}$.

- Mechanical testing, performed at elevated temperatures after thermal aging, has shown that there is no strengthening and no ductility loss at $800^{\circ} \mathrm{C}$ compared with the final annealing condition. At temperatures of 600 and $700^{\circ} \mathrm{C}$ a remarkable increase in yield strength as well as a decrease in elongation remains.

- The low carbon and niobium version Nicrofer 6020 hMo of alloy 625 in the solution annealed condition has the best capabilities for bellow and related applications at intermediate temperatures $\left(e .9 .600\right.$ and $\left.700^{\circ} \mathrm{C}\right)$. 


\section{References}

1. F. A. Comprelli and U. E. Wolf, United States Atomic Energy Commission, GEAP 4745 (1964).

2. F. A. Comprelli and J. E. Lewis, United States Atmomic Errergy Commission, GEAP-4751 (1965).

3. F. A. Comprelli, United States Atomic Energy Commission, GEAP 4794 (1965).

4. H. Böhm, K. Ehrlich and K. H. Kramer, Metall, Vol. 24, 1970, pp. 139-144

5. E. Schnabel, H. J. Schüller, P. Schwaab, Prakt. Metallographie, Vol. 8, 1971, pp. 521-527.

6. J. R. Crum, M. E. Adkins and W. G. Lipscomb, Performance of High Nickel Alloys in Intermediate Temperature Refinery and Petrochemical Enviroments, Paper No. 208, Corrosion 86, The National Association of Corrosion Engineers, Houston, Texas, 1986.

7. O. F. Kimball, W. R. Pieren and D. J. Robert, Effects of ElevatedTemperature Aging on the Mechanical Properties and Ductility of Ni-Cr-Mo-Nb Alloy 625, presented at the ASME Annual Winter Meeting, Detroit, Michigan, November 1973. 